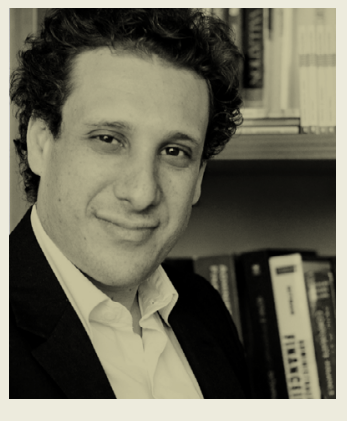

\title{
O DILEMA DOS CARRINHOS E BANDEJAS NÃO DEVOLVIDOS
}

A economia comportamental pode dar a impressão de lidar apenas com questões relacionadas ao consumo e às finanças, mas muitos estudos estão ligados aos rituais do nosso dia a dia. Por exemplo, por que muitas pessoas não devolvem o carrinho no supermercado ou a bandeja na praça de alimentação do shopping?

Uma das justificativas mais comuns é de que há alguém designado para fazê-lo. Alguns acreditam que deixar a bandeja na mesa ou abandonar o carrinho em qualquer lugar preserva ou até mesmo cria empregos das pessoas encarregadas do recolhimento.

Nada menos verdadeiro. O governo de Cingapura produziu um estudo que conclui: largar as bandejas nas mesas das praças de alimentação não faz diferença para os empregos.

O fato é que não existe a função de buscador de carrinhos ou recolhedor de bandejas. Funcionários que fazem essa tarefa são encarregados de várias outras. Quem não devolve no lugar certo, na realidade, sobrecarrega esses funcionários, prejudica o bem-estar dos outros consumidores e alimenta um ciclo vicioso de atitudes incorretas.

Em um experimento, cujos resultados foram publicados na revista Science, o sociólogo Siegwart Lindenberg e os psicólogos Kees Keizer e Linda Steg deixaram folhetos nos vidros de carros no estacionamento de um supermercado em duas situações: na primeira, os carrinhos de compra estavam todos no lugar certo e, na segunda, havia carrinhos espalhados pelo pátio. O que ocorreu foi que, na primeira situação, $30 \%$ dos motoristas jogaram os folhetos no chão. Já na segunda, em que havia carrinhos abandonados pelo estacionamento, esse percentual foi praticamente o dobro, $58 \%$.

A pesquisa parece confirmar um famoso experimento de criminologia que deu origem à Teoria das
Janelas Quebradas quase quatro décadas atrás. Se janelas de uma casa quebrarem e ficarem muito tempo sem reparo, vândalos primeiro irão arremessar pedras em outras janelas, depois a casa toda será depredada. Um pequeno delito pode levar a um maior, que leva a outro delito ainda maior, e assim por diante.

Como resolver o problema das bandejas e carrinhos abandonados? Há mais de uma década, o governo de Cingapura vem experimentando soluções. Em um país com praças de alimentação que funcionam nas ruas, a montanha de comida espalhada é um risco à saúde da população. Além disso, LARGAR AS BANDEJAS NAS MESAS DAS PRAÇAS DE ALIMENTAÇÃO NÃO ESTIMULA A GERAÇÃO DE EMPREGOS E SIM SOBRECARREGA OS FUNCIONÁRIOS QUE AS RECOLHEM. o recolhimento das bandejas acaba ficando a cargo de funcionários que, em sua maioria, são idosos e têm também de esfregar o chão, esvaziar lixeiras e, às vezes, até ajudar na cozinha.

Uma alternativa testada, comum na Europa, foi cobrar uma taxa pelo uso da bandeja, reembolsada depois da devolução. Não deu certo. O pagamento fez com que muitas pessoas considerassem que tinham o direito de ficar com as bandejas. Ou então, pior, nem as retiravam, deixando restos de comida direto na mesa. Outra alternativa foi pagar uma pequena quantia, equivalente a $R \$ 0,55$, para quem entregasse de volta a bandeja. Os comerciantes reclamaram que estavam tendo que arcar com o custo.

Foi uma terceira ideia que mais deu certo. Em vez de cobrar ou oferecer dinheiro, os shoppings e praças de alimentação a céu aberto passaram a colocar nas bandejas um pequeno cartão estimulando a devolução. O pessoal da limpeza reforça a atitude, ao circular pelas mesas com camisetas com mensagens pró-coleta. Se antes metade das pessoas não devolvia a bandeja, hoje são 3 em cada 10. Um círculo virtuoso pode se formar a partir do reforço positivo. 